\title{
POSSIBLE BREEDING PAIR OF CINNAMON TEAL IN THE THICKWOOD HILLS, SASKATCHEWAN
}

JOHN T. TREVOR, \#18-4231 Degeer Street, Saskatoon, Saskatchewan. $\mathrm{S} 7 \mathrm{H} 4 \mathrm{~N} 6$

There is only one confirmed breeding record of Cinnamon Teal in Saskatchewan - at Nicolle Flats near Moose Jaw in 1990. ${ }^{1}$ Additional records of possible breeders have been recorded, but many are confined to the southern and western portions of the province. ${ }^{2}$ This note reports the probable breeding of Cinnamon Teal in central Saskatchewan.

In 1990 I saw a potential breeding pair of Cinnamon Teal in the Thickwood Hills, while I was conducting research on a Canadian Wildlife Service study for Dr. Glen Adams. The study site was in the Royal P.F.R.A. Pasture, located approximately 20 $\mathrm{km}$ north of Blaine Lake, Saskatchewan.

As part of the study, waterfowl breeding pair censuses were conducted from early May until late
June. On 30 May, I observed a pair of Cinnamon Teal on a pond in the southwestern portion of the pasture. On subsequent breeding pair censuses, 8 and 14 June, a male Cinnamon Teal was observed on the pond adjacent to the one where the original pair was seen.

Although nest searches were conducted in this area, no nest was found. However, I believe that the initial pair observation and continued observation of the male represent a probable breeding pair of Cinnamon Teal in this area of the province.

1. KOES, R.F. and PETER TAYLOR. 1990. Prairie Provinces Region (Summer 1990). Am. Birds 44:1148-1149.

2. SMITH, A.R. and C.I.G. ADAM. An atlas of Saskatchewan birds. Canadian Wildlife Service and Saskatchewan Natural History Society, Regina. In press.

As in fall, our geese make daily trips to corn.... If I could understand the thunderous debates that precede and follow these daily excursions to corn, I might soon learn the reason for the prairie bias. But I cannot, and I am well content that it should remain as a mystery. What a dull world if we knew all about geese. Aldo Leopold. 1949. A Sand County Almanac. Oxford. 